\title{
THEATRE
}

\section{Here's looking at you}

The ninth annual season of the First Light Festival is under way in New York, offering new dramatic works exploring science and technology, commissioned by the Ensemble Studio Theatre and the Alfred P. Sloan Foundation. The centrepiece is the premiere of Serendib, a play by David Zellnik, inspired by two months the author spent with a team of primatologists studying toque macaques in Sri Lanka. The play focuses on scientists George Fischke and Anna Sunilagatte, who try to test the hypothesis that occasional violent takeovers of one troop of macaques by an outside alpha male adversely affects the troop's happiness. But money is short, so the scientists turn to two vaguely disreputable documentary filmmakers for some much-needed publicity. The film-makers bring along Dmitri Ramsov, a geneticist who has no use for Fischke's woolly theories about the soulfulness of macaques. The stage is thus set for two mirrorimage plays, with Fischke and

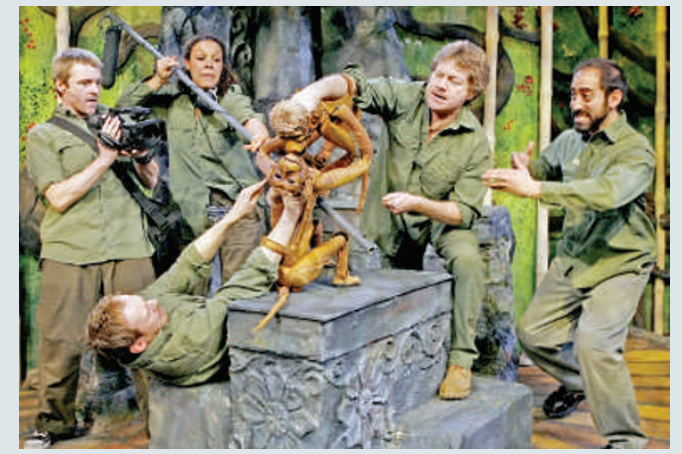

television provides comic relief, but the play persists with its themes: the roles of observation and experiment in science, the distorting lens of media coverage, and the debate over the relative importance of heredity and environment in behaviour. It reaches a moving climax as Fischke and Ramsov deliver eloquent tributes to two of the macaques, their

Ramsov vying for supremacy and the affections of Sunilagatte, and the macaques under observation - puppets controlled by the actors - acting out a parallel drama. The film-makers' search for good words illustrating the differences between humans and our primate cousins, and the powerful, if elusive, similarities. Alan Packer http://ensemblestudiotheatre.org/ index $3 . h t m l$

\section{No firm promises}

\section{Science Business: The Promise, the Reality, and the Future of Biotech by Gary P. Pisano \\ Harvard Business School Press: 2006. 256 pp. $\$ 29.95$}

\section{Keith Redpath}

I have an aversion to management books, and it is based on the way they are written. Why use a sentence when a chapter will do? Why use standard English when you can invent meaningless phrases? Gary Pisano suffers from this predilection in his book Science Business. He takes more than 70 pages to tell the reader that drug discovery is complex and risky, involving several disciplines and lots of money, and that biotechnology has simply increased the complexity. A further 30 pages are required to conclude that many commercialization strategies are being followed, but that it is too early to know which are right.

What Pisano does, however, which few have dared to do in print before, is the biotechnology equivalent of the boy who shouted out that the Emperor had no clothes. He poses the question: "can science be a business?" He concludes, on the basis of his research and the experience of biotechnology to date, that the answer is no, but that the industry still has time to exonerate itself, if only it can change.

Modern biotechnology was depicted at its inception as a huge danger to mankind. Genetic manipulation was either carried out behind greater security than was required for the reprocessing of nuclear waste, or it was banned altogether. We were told that mad scientists would release modified microbes that would wipe out mankind. The hysteria parallels that accompanying stem cells and nanotechnology some 30 years later and perhaps demonstrates one of Pisano's theses: that the industry fails to learn from its mistakes.

Biotechnology was soon repositioned as the saviour of mankind. No disease was immune to attack from the magic bullet of biotechnology. Shares soared. Investors cashed in and got rich. Many more companies formed. Universities saw ways of making money from research.

Despite that, Pisano contends that the industry has failed to deliver financially. He may be right, but his analysis is flawed. Many small start-up companies with promising drug candidates or technologies are acquired by larger companies before making a profit, delivering good returns for founders and investors. In deciding whether biotechnology has delivered financially, Pisano considers the profitability of those that remain independent. But this is not necessarily the best measure, as these companies may be the ones that are doomed to fail. To be fair, he does warn that care should be taken when drawing conclusions from analyses of the output of the biotechnology sector.

The book asks a fundamental question about the financing of biotechnology: are the public equity markets the right place for biotechnology companies to raise their money? Pisano argues that structurally the answer is no, as investors can never have enough information on which to arrive at a valuation of an $\mathrm{R} \& \mathrm{D}$ programme in a revenue-less company.

In part, this depends on the reader's view of what an equity market exists to achieve. Mine is that equity markets are where companies seek capital. Not all companies succeed, with consequences for investors who, historically, accepted that potential large returns come with significant risk. Analysts would never recommend investing in a single biotechnology company, always presenting the industry as a portfolio play: nine companies will fail, but the tenth will deliver more than enough of a return to compensate. This highlights a transatlantic difference in the public equity markets that Science Business, with its focus on the United States, does not capture: the majority of investment in biotechnology on the London markets is institutional, a source of capital that can afford to invest in multiple companies and to take a long-term view.

More information is not the answer. Investors in biotechnology can already access accounts, scientific literature, conference proceedings and patents, and are updated by companies in some detail. This is more information than an investor in WalMart, say, might receive. Most investors are not, however, equipped to interpret these data.

Pisano concludes that the industry's failings can be corrected by better integration, better communication of information and better long-term learning. The evidence presented to support these conclusions is US-centric and therefore incomplete. Different strategies pursued elsewhere to encourage these solutions are not examined.

Science Business contains some useful facts but their value depends on the intended readership. For example, chapters 2 and 3 contain simple, if wordy, definitions of the many '-omics' in the biotechnology industry and a description of the drug development process. These are useful to those outside the industry but insiders can skip these chapters.

According to the sleeve notes, the book "provides clear prescriptions for companies, investors and policymakers seeking ways to improve the industry's performance". But does it? Read this book if you have an interest in the history of the commercialization of biotechnology, in how the industry works, and if you want to know what the issues facing the industry are. Just don't expect to find the answers it promises, merely a description of some of the options.

Keith Redpath is chief executive of Opal Drug Discovery, 41 Heriot Row, Edinburgh EH3 6ES, UK. 